\title{
Indonesian Journal of Chemical Science and Technology
}

State University of Medan

e-ISSN : 2622-4968, p-ISSN : 2622-1349

IJCST-UNIMED, Vol. 02, No. 2, Page; 131 - 135

Received : June 23, 2019

Accepted : July 5, 2019

Web Publised ; July 10, 2019

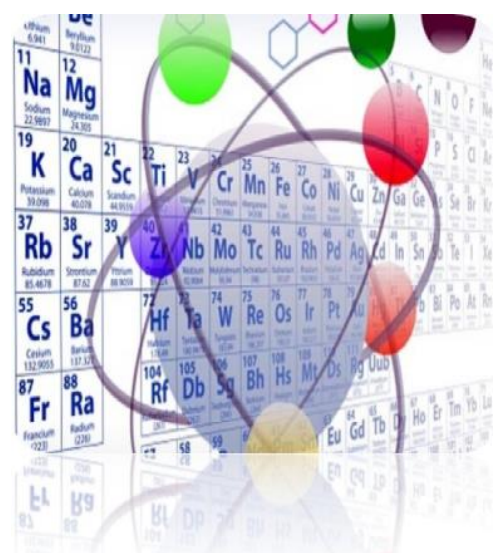

\section{$\mathrm{Pb}$ (II) and Oil Contamination Analysis of Belawan Sea, Medan City, North Sumatera}

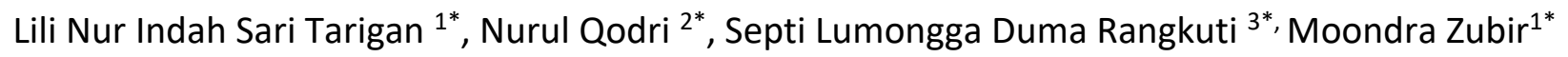

1 Jurusan Kimia, Fak. Matematika dan IImu Pengetahuan Alam, Universitas Negeri Medan

2Fakultas Teknik, Universitas Negeri Medan

3Jurusan Matematika, Fak. Matematika dan IImu Pengetahuan Alam, Universitas Negeri Medan

Email: moondrazubir@unimed.ac.id

\begin{abstract}
Belawan waters are very densely populated with shipping, industrial and settlement. These various activities have an impact in the form of sea pollution by liquid waste such as Pb (II) and oil. Based on the results of the analysis of the content of $\mathrm{Pb}$ (II) in the highest waters, which is equal to 26.9120 ppm, it exceeds the threshold. The oil content in the waters has exceeded the threshold of $0.05 \mathrm{gr} / \mathrm{L}$. One way to reduce the levels of Pb (II) and oil is by using coconut husk biosorbent. This is evidenced by the results of the analysis that there was a decrease in Pb (II) metal content after adsorption using coconut coir biosorbent which was equal to 6.2430ppm with adsorption capability of 20,699 ppm. The oil content in the water after the water is adsorbed using coconut coir biosorbent shows the Not Applicable result because the seawater sample has been homogenized so that no significant changes occur. This shows that coconut coir biosorbent is effective to reduce the content of Pb and Oil in water in the waters of the sea.
\end{abstract}

Keywords: Wild sea pollution, Pb (II) metal, biosorbent, coconut fiber, Oil

131 


\section{Introduction}

Sea pollution is a problem that is widely discussed in the world, especially Indonesia. The sea is the estuary of all community activities and industrial activities that indicate the high potential of sea water pollution. ${ }^{1}$ According to Darmono ${ }^{2}$ the sea receives materials that are carried by water from agricultural areas, household waste, garbage, waste material from ships, oil spills, and other waste materials. Pollutant loads that have exceeded the sea water quality threshold will cause the sea has been polluted and does not function in accordance with its purpose. If the sea has been polluted by various marine debris continuously with large volumes in high concentrations, it will cause the sea to no longer be able to purify because it has exceeded its carrying capacity so that it damages the sea balance.

Belawan waters are open sea waters that are directly related to the Deli River basin. Deli River is one of the rivers that divides the city of Medan to North Medan and empties into Belawan Waters. The Belawan area is an international port area filled with industry and settlements and other public facilities. At present there are around 35 industries such as Crude Palm Oil (CPO) storage, fertilizer industry and cement industry in the Belawan environment. 4 One of the causes of belawan waters pollution is heavy metals and oil spills which can be a serious problem. ${ }^{3,4}$

The content of heavy metals that have exceeded the threshold will be very dangerous if it enters the body and can interfere with human health. One of the heavy metals contained in belawan waters is $\mathrm{Pb}$ (II) metal. Lead metal $(\mathrm{Pb})$ has toxic properties that can interfere with health and cause death. High lead content can be traced to industrial waste from various sources, such as electric battery manufacturing, lead smelting, and mining activities. Lead in drinking water is known to cause various types of serious health problems that can cause death in cases of extreme exposure. ${ }^{5}$ Lead $(\mathrm{Pb})$ is a type of heavy metal that has the potential to become a contaminant, because it is a compound that lasts a long time in a water bodies before finally settling or absorbed by the various physical and chemical reactions in the waters. ${ }^{5,9}$

Oil pollution at sea (oil spill) is a very important environmental problem. ${ }^{13}$ Oil spills at sea, especially large scale oil spill accidents, have posed a major threat and caused extensive damage to the coastal environment. Contaminants can accumulate in the body of marine organisms and are harmful to humans. ${ }^{3,13}$ Based on the results of field observations, it appears that people around the use of water in Belawan waters directly to meet the water needs in everyday activities. The metal content of $\mathrm{Pb}$ (II) and oil can accumulate in the body. If this situation continues for a long period of time, it can endanger human health.

Considering the negative impact of $\mathrm{Pb}$ (II) metal and oil on living things and the environment, an effort is needed to control the presence of these two hazardous liquid wastes. One way to reduce metal and oil content is through the process of adsorption by coconut coir biosorbents.

Coconut coir is one of the biomass that is easily obtained and is a byproduct of agriculture. The composition of coir in coconuts is about $35 \%$ of the total weight of coconuts. Coconut coir consists of fiber (fiber) and cork (pitch) that connects one fiber to another fiber. Coconut coir consists of $75 \%$ fiber and $25 \%$ cork. 12 The potential use of coconut fiber as biosorbent to remove heavy metals from the waters is quite high because coconut coir fiber contains lignin $(35 \%-45 \%)$ and cellulose (23\% - 43\%). 1,12 Thus it is expected that coconut coir biosoben can absorb and reduce the metal content of $\mathrm{Pb}$ (II) and oil in belawan sea waters.

\section{Experimental Method}

The materials used in this study were dry coconut coir obtained from Tembung village of Deli Serdang Regency, Sodium hydroxide $(\mathrm{NaOH})$, aquadest, water samples from Belawan waters, Chloride Acid ( $\mathrm{HCl})$ 1:1, $\mathrm{Na}_{2} \mathrm{SO}_{4}$ anhydrous, nHexane. Glassware used are separating funnel, erlenmeyer, glass funnel, filter paper, measuring flask, measuring pipette, oven, beaker glass, coarse filter paper, scales, desiccators, set of glassware, volume pipettes, suction balls, $\mathrm{pH}$ meters, ovens, and analytical balance, magnetic stirrer. Sample analysis is carried out in a laboratory by using atomic absorption spectrophotometry (AAS). Sampling was carried out at three observation points, the location of sampling was determined by positive 
sampling, in a sequence that is PLTU, mangrove areas, residential areas.

\section{Preparation of $\mathrm{NaOH}$-activated biosorbents.}

Coconut fiber is washed thoroughly and rinsed with distilled water, then dried in the sun. After drying, the sample is cut into small pieces with a size of 1-2 mm. Then washed with distilled water until clean. The sample is then dried in an oven at $70^{\circ} \mathrm{C}$ until a constant weight is obtained and stored in a desiccator.

\section{Biosorbent Activation.}

573 grams of biosorbent was put into $7162.5 \mathrm{~mL}$ of $1.2 \mathrm{M}$ sodium hydroxide $(\mathrm{NaOH})$ solution. The mixture was stirred for 2 hours, then filtered and the residue washed with distilled water to a neutral $\mathrm{pH}$ $(\mathrm{pH} 7)$. Biosorbent is dried in an oven at 70 , then stored in a desiccator.

\section{Oil Extraction}

A sample of $500 \mathrm{~mL}$ containing Belawan seawater acidified by adding 1: 1 Hydrochloric Acid $(\mathrm{HCl})$ until the $\mathrm{pH}$ was less than 2 , then extracted with nhexane as much as $100 \mathrm{~mL}$ for 2 minutes. Let the water and n-hexane layers separate. The water phase is separated into erlenmeyer, while the n-hexane phase layer is passed through filter paper containing 10 grams of anhydrous sodium sulfate (Na2SO4) and accommodated in a distillation flask with known weight (Wo). The n-hexane phase layer is distilled with a water bath at temperature. When the solvent condensation is stopped, the distillation is stopped. Cool and dry the distillation flask in the oven with a temperature of \pm for $30-45$ minutes. The distillation ash is put into the desiccator for 30 minutes and weighed the distillation flask until a fixed weight (W1) is obtained. The oil level is calculated.

\section{Results and Discussion}

The results of the analysis of $\mathrm{Pb}$ metals in belawan waters using AAS indicate that the $\mathrm{Pb}$ (II) metal content in belawan sea waters has exceeded the $\mathrm{Pb}$ (II) metal quality standards in sea waters. $\mathrm{Pb}$ (II) metal analysis results in belawan waters can be seen in Table 1.
Table 1. Results of the analysis of the metal content of $\mathrm{Pb}$ (II) in belawan waters before treatment

\begin{tabular}{c|l|c}
\hline No & Sample Point & $\mathrm{Pb}(\mathrm{ppm})$ \\
\hline 1 & PLTU & 24.13 \\
\hline 2 & Mangrove Area & 26.91 \\
\hline 3 & Fisherman Area & 11.18 \\
\hline
\end{tabular}

The results of the analysis showed that there were differences in the metal content of $\mathrm{Pb}$ (II) in belawan sea waters at each sampling point. Lead metal content in Belawan waters at 3 points has exceeded the Lead metal content threshold in port waters. Based on the quality standard limits set by the Minister of Environment No. 51 of 2004 in annex 1 concerning seawater quality standards for port waters, the $\mathrm{Pb}$ (II) metal quality standard value is $0.05 \mathrm{mg} / \mathrm{L}$. The metal content of $\mathrm{Pb}$ (II) at three sampling points has exceeded the specified quality standard threshold. The content of $\mathrm{Pb}$ (II) in the power plant is $24.1255 \mathrm{ppm}$. The high content of $\mathrm{Pb}$ (II) in the power plant is due to the area being an industrial waste disposal in Belawan waters. Lead $(\mathrm{Pb})$ is widely used in industry for example as a fuel additive, lead pigment in paint which is a major cause of increased $\mathrm{Pb}$ levels in the environment.8 According to (Walker et al., 1998) that if pollution occurs it is suspected that the main source of lead $(\mathrm{Pb})$ comes from the residual combustion of motor vehicle exhaust gases and paint. So that metals in the waters will accumulate in the sediment. ${ }^{14}$

The content of $\mathrm{Pb}$ (II) in the mangrove area is $26.9120 \mathrm{ppm}$. The content of PB (II) in the mangrove area is classified as very high due to the mangrove area close to the location of the power plant. The lowest $\mathrm{Pb}$ (II) content is located in the fishing village of $11.1780 \mathrm{ppm}$. This is due to the fishing village located in residential areas that tend not to be dense with industrial activities that cause $\mathrm{Pb}$ metal contamination. Resulting in a dilution of the residents' activities which can cause $\mathrm{Pb}$ (II) metal content to decrease in belawan sea waters.

Lead $(\mathrm{Pb})$ is a heavy metal that is very toxic and is not needed by humans, so that if food is contaminated by the metal, the body will release it. ${ }^{6}$ In the human body $\mathrm{Pb}$ metal can inhibit the activity of enzymes involved in the formation of hemoglobin (Hb) and a small portion accumulates in the kidneys, liver, fat tissue and hair. ${ }^{15}$ 
One of the most dangerous pollutants for human health is heavy metals. World Health Organization (WHO) or the World Food and Agriculture Organization (FAO) recommends not to consume seafood (seafood) that is contaminated with heavy metals. Heavy metal has long been known as an element that has the potential for poison and has the ability to accumulate in the organs of the human body. In fact, not a few cause death. Some dangerous heavy metals are mercury or mercury $(\mathrm{Hg})$, Cadmium $(\mathrm{Cd})$, Lead $(\mathrm{Pb})$, Copper $(\mathrm{Cu})$, and others. ${ }^{2}$

This research uses adsorption method using coconut coir biosorbents. Water samples from three sampling points are absorbed using coconut coir biosorbents. $\mathrm{Pb}$ (II) metal analysis results in belawan waters after receiving treatment was observed in Table 2 .

Table 2. Results of analysis of $\mathrm{Pb}$ (II) metal content in belawan waters after treatment

\begin{tabular}{c|l|c}
\hline No & Sample Point & $\mathrm{Pb}(\mathrm{ppm})$ \\
\hline 1 & PLTU & 7.04 \\
\hline 2 & Mangrove Area & 6.24 \\
\hline 3 & Fisherman Area & 4.14 \\
\hline
\end{tabular}

The results of the $\mathrm{Pb}$ metal analysis after treatment showed that there was a decrease in the $\mathrm{Pb}$ (II) metal content after being adsorbed by the biosorbent of coconut coir in water samples in belawan waters. $\mathrm{Pb}$ (II) metal adsorbed at sample point 1 , sample 2, and sample 3 were $17.0875 \mathrm{ppm}$, $20.669 \mathrm{ppm}$, and $7.038 \mathrm{ppm}$, respectively. This shows that biosorbents adsorb $\mathrm{Pb}$ (II) metal well during experiments.

The results of the analysis of oil content in Belawan waters amounted to $0.05 \mathrm{gr} / \mathrm{L}$. This shows that the oil content in Belawan waters has exceeded the oil content threshold in the port waters area stipulated by the Ministry of Environment No. 51 of 2004 which is $5 \mathrm{mg} / \mathrm{L}$ is equivalent to $0.005 \mathrm{gr} / \mathrm{L}$.

Table 3. Results of oil content analysis in belawan waters after treatment

\begin{tabular}{c|l|c}
\hline No. & \multicolumn{1}{|c|}{ Sample Point } & Minyak (gr/L) \\
\hline 1. & PLTU & NA \\
\hline 2. & Mangrove Area & NA \\
\hline 3 & Fisherman Area & NA \\
\hline
\end{tabular}

The trial was conducted at three sampling points and homogenized. The results of the analysis of oil content in belawan sea waters after the treatment showed Not Applicable results due to sea water samples had been homogenized so that no significant changes occurred. Coconut coir fibers are very potential as biosorbents because they contain cellulose that is inside its molecular structure contains carboxyl groups and lignins which contain phenolic acids which take part in the binding of metals. Cellulose and lignin are biopolymers associated with the process of separating heavy metals.11 The results of the analysis of the decreased $\mathrm{Pb}$ (II) metal content and oil content in belawan waters indicate that coconut coir biosorbents are effective in absorbing $\mathrm{Pb}$ (II) metal and oil.

\section{Conclusion}

Based on the analysis of $\mathrm{Pb}$ (II) metal content in belawan waters, it was concluded that the $\mathrm{Pb}$ (II) metal contamination had passed the threshold of $\mathrm{Pb}$ (II) metal content in port waters, $\mathrm{Pb}$ (II) content in PLTU was $24.1255 \mathrm{ppm}$, in the area mangrove at $26.9120 \mathrm{ppm}$, and in fishing villages at $11.1780 \mathrm{ppm}$. The results of the analysis of oil content in Belawan waters amounted to $0.05 \mathrm{gr} / \mathrm{L}$. The results of the analysis of the $\mathrm{Pb}$ (II) metal content after adsorption by using biocarp coir biosorbents showed a decrease in the $\mathrm{Pb}$ (II) metal content. $\mathrm{Pb}$ (II) metal adsorbed at sample point 1 was $17.0875 \mathrm{ppm}$, at sample point 2 it was 20,669 ppm, and at sample point 3 it was 7,038 ppm. As for the results of the analysis of oil content in belawan sea waters after treatment showed Not Applicable results. Based on the results of the analysis of the metal content of $\mathrm{Pb}$ (II) and oil show that coconut coir biosorbents are effective in adsorbing $\mathrm{Pb}$ (II) metal and oil.

\section{References}

1. Carrijo, O. A., Liz, R. S., Makishima, N.(2002). Fiber of Green Coconut shell as Agriculture substratum.Brazilian Horticulture. 20, pp. 533535.

2. Darmono. (2001). Lingkungan Hidup dan Pencemaran (Hubungannya dengan Toksikologi Senyawa Logam).Universitas Indonesia Press. Jakarta. 
3. Dwi, Ajeng. (2011). Perbandingan Biostimulasi dan Bioaugmentasi dalam Bioremediasi Pantai Tercemar Minyak Bumi. Skripsi. Fakultas Teknik. Universitas Indonesia.

4. Grace, L., T.Z. Ulqodry., dan W.A.E. Putri. (2010). Kandungan Logam Berat $\mathrm{Pb}$ dalam Muatan Padatan Tersuspensi dan Terlarut di Perairan Pelabuhan Belawan dan sekitarnya, Provinsi Sumater Utara. Maspari Journal 02 (2), pp. 48-53.

5. Hui Niu, Xue Shu Xu, and Jian Hua Wang,. (1993). Removal of Lead from AqueousSolutions by Penicillium Biomass. Chengdu University of Science and Technology.

6. Hardiani, H., Ardiansyah, T. \& Sugesti, S. (2011). "Blok mediasi logam timbal $(\mathrm{Pb})$ dalam tanah terkontaminasi limbah sludge industri kertas proses deinking". Jurnal Selulosa. 1(1), pp. 3141.

7. Keputusan Menteri Negara Lingkungan Hidup Nomor 51 tahun 2004 tentang baku mutu air laut.

8. Lu, F.C. (1995). Toksikologi dasar. UI-Press. Jakarta.

9. Mukhtasor. (2002). Pencemaran Pesisir Dan Laut. Pradnya Paramita. Jakarta.

10. Peraturan Pemerintah Republik Indonesia. (2001). Peraturan Pemerintah Republik Indonesia Nomor 82 Tahun 2001 Tentang Pengelolaan Kualitas Air dan Pengendalian Pencemaran Air.

11. Pino, G. H., Mesquita, L. M. S., Torem, M. L., and Pinto, G. A. S. (2005). Biosorption of Cadmium by Green Coconut Shell Powder. Metallurgy and Material. 225Gavea, 22453-900 Rio de Janeiro-RJ. Brazil.

12. Sudiarta. Wayan. Dan Sahara. Emmy. (2011). "Biodorben $\mathrm{Cr}$ (II) pada biosorben serat sabut kelapa teraktivasi sodium hidroksida $(\mathrm{NaOH})$ ". Jurnal Kimia. 5 (2), pp.133-142.

13. Yasmin.Zhafira. dan Wulansarie. Ria. (2017). "Review Perbandingan Pencemaran Minyakdi Perairan Dengan Proses Bioremediasi Menggunakan Metode Biostimulus Dab Bioaugmentasi”. Jurnal Reka Buana. 3(1), pp. $67-$ 72.

14. Warni, Desi., Karina, S., dan nurfadillah. (2017). Analisis Logam Pb, Mn, Dan Cd Pada Sedimen Di Pelabuhan Jetty Meulaboh, Aceh Barat. Jurnal
Ilmiah Mahasiswa Kelautan dan Perikanan Unsyiah. 2(2), pp. 246-253.

15. Widyowati, W., Sastiono, A. \& Jusuf, R. (2008). Efek Toksis Logam Berat Pencegahan Dan 